\title{
Tsunamigenic, earthquake-triggered rock slope failures during the April 21, 2007 Aisén earthquake, southern Chile $\left(45.5^{\circ} \mathrm{S}\right)$
}

\author{
Sergio A. Sepúlveda ${ }^{1}$, Alejandra Serey ${ }^{1}$ \\ 'Departamento de Geología, Facultad de Ciencias Físicas y Matemáticas, Universidad de Chile, Casilla 13518, Correo 21, Santiago, Chile. \\ sesepulv@ing.uchile.cl; aserey@ing.uchile.cl
}

\begin{abstract}
The April 21, 2007 shallow crustal earthquake (Mw 6.2) in the Aisén Fjord area triggered hundreds of landslides around the epicentral zone. Among those, several rock slope failures such as rock slides, rock falls and rock avalanches were induced on the steep fjord slopes. The violent impact of the disrupted rock masses into the fjord generated local tsunamis that caused ten fatalities and extensive damage to salmon farms located along the fjord shores. Field observations suggested that geotechnical and geomorphological factors controlled the landslide locations and failure modes, associated with the presence of faults and topographic relief, respectively. This event is an example of a geological hazard that has not been previously addressed in the Chilean Patagonian fjordland, revealing the need for identifying and understanding these geological phenomena in future hazard assessments in the region.
\end{abstract}

Keywords: Landslides, Earthquakes, Geological hazards, Aisén, Chile.

RESUMEN. Inestabilidades de laderas de roca generadoras de tsunami durante el terremoto de Aisén del 21 de abril de 2007, sur de Chile (45.5 $\mathbf{~ S ) . ~ E l ~} 21$ de abril de 2007 un terremoto superficial cortical (Mw 6,2) en el área del Fiordo Aisén desencadenó cientos de remociones en masa en la zona epicentral. Entre éstas, se generaron varias inestabilidades en laderas rocosas escarpadas, tales como deslizamientos, caídas y avalanchas de rocas. El violento impacto de las masas disgregadas de roca en las aguas del fiordo generó tsunamis locales, que causaron diez víctimas fatales y un importante daño en granjas salmoneras ubicadas a lo largo de las costas del fiordo. Observaciones de terreno sugieren controles geotécnicos y geomorfológicos en la ubicación y modos de falla de las remociones en masa, asociados a la presencia de fallas y relieve abrupto, respectivamente. Este evento es un ejemplo de un tipo de peligro geológico que no ha sido previamente detectado ni abordado en los fiordos de la Patagonia Chilena, revelando la necesidad de identificar y comprender estos fenómenos geológicos en futuras evaluaciones de peligro en la región. 


\section{Introduction: The 2007 Aisén Fjord earth- quake}

On April 21, 2007, a Mw 6.2 (Ms 6.3) earthquake (Global CMT Catalog, 2008; NEIC, 2008) occurred at about 13:50 local time in the Aisén Fjord, Chilean Patagonia (45.5 ${ }^{\circ}$, Fig. 1). The intensities reported by the Chilean Seismological Survey reached VII in the nearby towns of Puerto Aisén and Puerto Chacabuco (Fig. 2). The earthquake represented the peak of a seismic swarm that started on January 22, 2007. During this period, thousands of tremors were detected in the area (Barrientos et al., 2007; Comte et al., 2007). After the April main shock, the activity decreased significantly. The focus depth of the main shock was placed around 12 $\mathrm{km}$ according to the global network (CMT Global Catalog, 2008), although several works suggest that it may have been shallower (Naranjo et al., 2009, this volume; Barrientos 2007, personal communication). Most of the local seismic network installed during the seismic swarm was damaged or lost due to the tsunamis, avoiding a precise location of the hypocentre (Naranjo et al., 2009, this volume). The main shock focal mechanism was strike-slip with a north-south plane solution (CMT Global Catalog, 2008), which fits the orientation of one of the main mapped branches of the Liquiñe-Ofqui Fault Zone (LOFZ), a regional right-lateral strike-slip structure that accommodates the parallel component of the oblique subduction of the Nazca plate beneath the South American plate (e.g., Cembrano and Hervé, 1993; Cembrano et al., 2002; Fig. 1). A source relationship between the LOFZ and the earthquake is discussed by Cembrano et al. (2007), Comte et al. (2007) and Naranjo et al. (2009, this volume). The local geology of the epicentral area is fundamentally composed of intrusive rocks of the North Patagonian Batholith, volcanic deposits from the nearby Hudson, Macá and Cay stratovolcanoes, alluvial sediments and a series of small monogenetic cones (Niemeyer et al., 1984; Lahsen et al., 1997). The

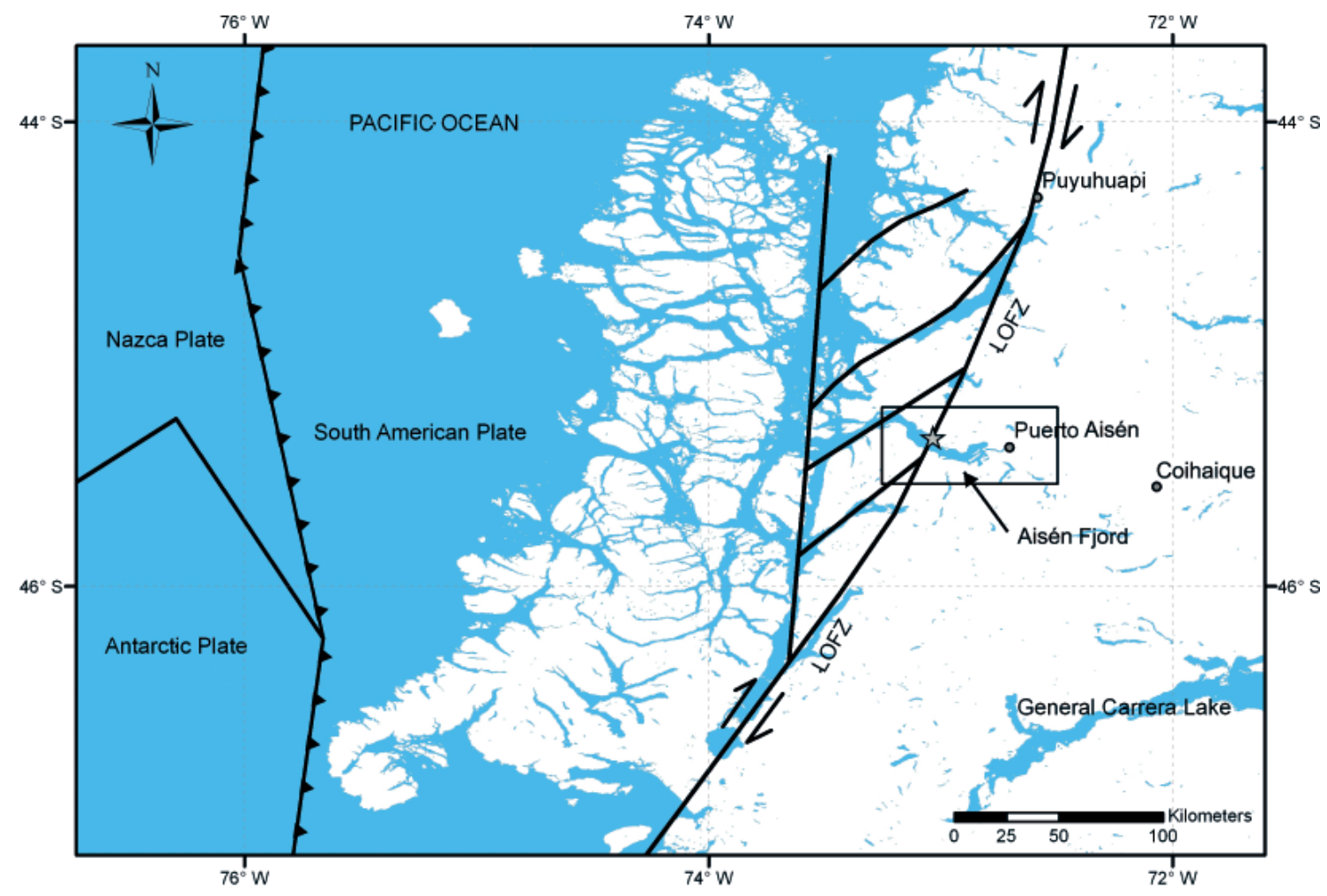

FIG. 1. General tectonic setting of Chilean Patagonia between $44^{\circ}$ and $47^{\circ} \mathrm{S}$, indicating the Liquiñe-Ofqui Fault Zone (LOFZ), the area where earthquake-induced landslides were recognized (box) and the April 21, 2007 earthquake epicentral zone (star), after Cembrano et al. (2002) and Sepúlveda et al. (2008). 


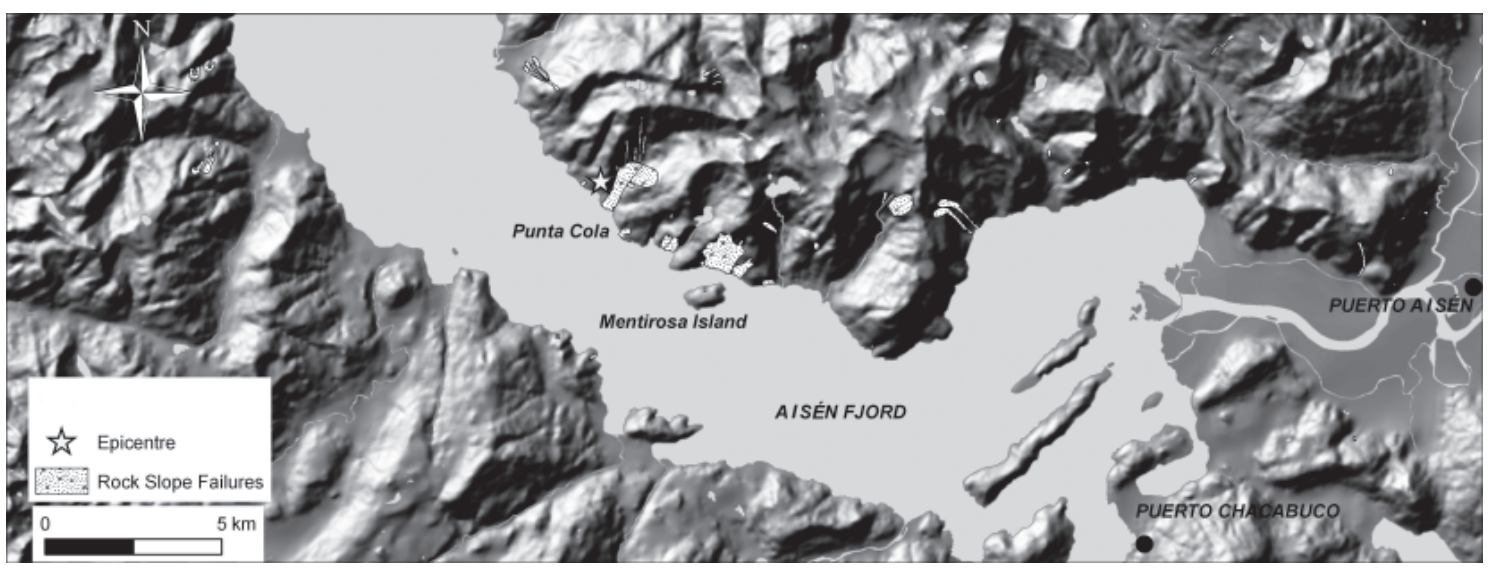

FIG. 2. Digital terrain model of the epicentral area represented as a shaded relief map, showing the approximate location of the April 21, 2007 earthquake epicentre by the Seismological Survey (Barrientos, 2008, personal communication) and the main mapped rock slope failures along the fjord shores and nearby areas.

slopes of the fjord and U-shaped tributary valleys are covered by a thin (less than $2 \mathrm{~m}$ ) layer of volcanic soils and vegetation.

The main shock triggered over three hundred landslides in the epicentral area (Sepúlveda et al., 2008a), in addition to a few ones that have been previously induced during the largest foreshocks. These landslides have been mapped and described by Naranjo et al. (20071, 2009), Pavez et al. (2007), Arenas et al. (2008) and Sepúlveda et al. (2008a, 2008b). The mass movements can be classified as shallow soil and soil-rock slides, rock slides, rock falls, rock avalanches and debris flows, and were distributed along the slopes of glacial valleys around the fjord as well as on the steep fjord slopes (Sepúlveda et al., 2008a, 2008b).

This short note is focused on the rock slope failures (see Glossary) that were induced by the April 21 earthquake along the fjord shoreline, which were the source of the tsunamis and configure a complex geological hazard, such as the sequence earthquake-landslide-tsunami. This kind of hazard has significant implications that should be studied in general for all populated fjords or with industrial activities along the LOFZ. A more comprehensive study of these and the other landslides induced by the earthquake is being carried out by the authors and will be published in the near future. A more extended account of the general effects of the April 21 earthquake and the landslide-tsunami relationships is being published by Naranjo et al. (2009, this volume).

\section{Rock slope failures in the Aisén Fjord}

\subsection{Rock Slides and Rock Avalanches}

The largest and most significant tsunamigenic landslides (Glossary) were disrupted rock slides that rapidly evolved to rock avalanches. This kind of failure was restricted to high and steep slopes along the fjord shore and close to it in narrow lateral valleys (Fig. 2). The rock slides (Glossary) were character-ized by massive, mainly translational movements of rock that were rapidly disintegrated. In many cases, the slides did not show significant structural control by joint surfaces dipping out of the slopes, but tended to occur in highly fractured rock around shear or fault zones, where the geotechnical quality of the rock mass is reduced. Their thicknesses varied in general between 5 and $15 \mathrm{~m}$, which can be considered as shallow given the slope heights where they occurred, which vary between $c a$. 200 and $1000 \mathrm{~m}$. The rock slides mainly occurred along the northern fjord shore, the most significant of which are a landslide complex in front of Mentirosa Island and a large slide in a ravine next to Punta Cola (Figs. 2, 3 and 4). The estimated volumes of these landslides are 7 and 12 millions of cubic metres, respectively (Clavero et al., 2008). A less volumetric shallow soil and rock slide in the southern shore also generated a smaller tsunami southwest of Mentirosa Island (Clavero et al., 2008; Naranjo et al., 2009 , this volume).

1 Naranjo, J.A.; Arenas, M.; Clavero, J.; Lara, L. 2007. Estudio preliminar de peligros por remociones en masa en la zona afectada por el sismo (Mw 6,2) del 21 de abril de 2007, Región de Aisén. Servicio Nacional de Geología y Minería, mayo de 2007 (unpublished report). 
The disrupted nature and high kinetic energy of the largest rock slides allowed them to transform into rock avalanches (see Glossary). The slides next to Mentirosa Island discharged directly into the fjord water, thus it is not clear whether they can be regarded as avalanches. On the other hand, the large rock slide in the ravine close to Punta Cola stripped vegetation from the opposite slope as it continued downstream, with marks indicating heights of over $20 \mathrm{~m}$ (Fig. 4). These marks and the deposits of more than $10 \mathrm{~m}$ thick along the gully, suggest a rock avalanche mechanism. The avalanche traveled for about $1 \mathrm{~km}$ before it reached the fjord.

\subsection{Rock Block Slides and Rock Falls}

The second failure mode found in rock slope failures are rock block slides (Glossary, Fig. 5) that in many cases transformed into rock falls due to the high steepness of the fjord coastal bluffs and some glacial valley slopes inland. Some rock falls (Glossary) could also have been induced by tensile failure along subvertical cracks and joints. Mobilized volumes are highly variable, and can reach up to dozens of thousands of cubic metres.

\section{Discussion and conclusions}

Whereas the landslides that affected the soil slope cover and the debris flows, which are com-

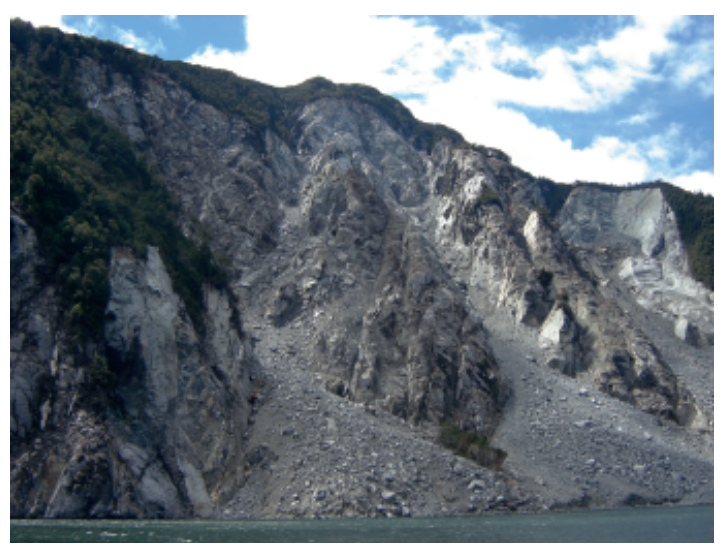

FIG. 3. Rock slide complex on the northern shore of Aisén Fjord, in front of Mentirosa Island (location in figure 2). Three main rock slides that stripped the vegetation out can be observed along with debris cones that form the non-submerged part of the deposit of disintegrated rock.
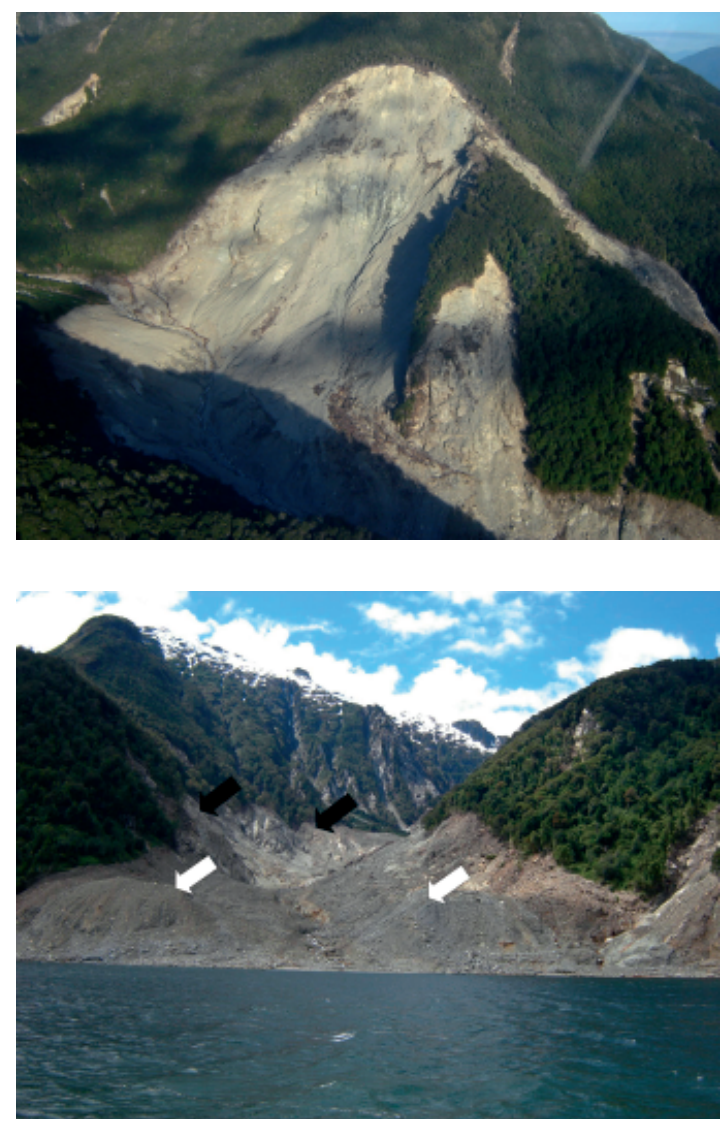

FIG. 4. Rock slide and avalanche in a ravine in the Punta Cola area (location in figure 2). The upper photo shows the $\sim 12$ million $\mathrm{m}^{3}$ rock slide on the eastern ravine slope. The bottom photo shows the erosion marks (black arrows) and deposits of the rock avalanche (white arrows) along the ravine.

mon around the epicentral area and also occur further away in the case of older events, seem to be related to the high susceptibility of the slopes to fail during either seismic or rainfall triggers, the tsunamigenic rock slope failures seem to be much more spatially restricted to zones where certain geomorphological, geotechnical and geological features can be found.

The large massive rock slides were triggered close to the epicentre, in areas where the observed intrusive rocks are more intensively fractured due to the presence of faults related to the major LiquiñeOfqui Fault Zone. Furthermore, the massive rock slides have particular characteristics, such as their shallowness, translational movement, disruption of the rock mass, and the location of the landslide 

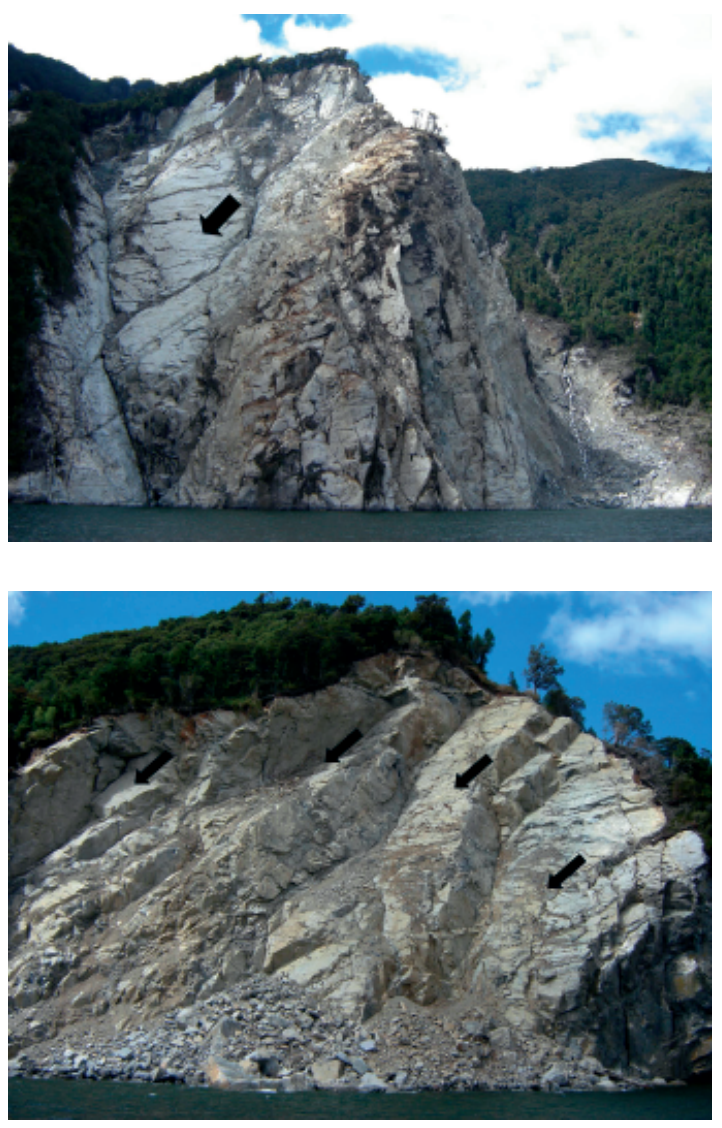

FIG. 5. Rock block slides and falls on the northern fjord shore. Arrows show the sliding surfaces composed of preexisting joints.

crowns at or very near the hillside tops. These characteristics are very similar to earthquake-triggered rock slides elsewhere that have been associated with the effect of topographic amplification of the seismic waves (Sepúlveda et al., 2005a, b). Topographic amplification is a local site effect inducing very high accelerations at the slope crest, which may generate landslides in slopes that otherwise would be sufficiently strong to resist such large mass movements. This hypothesis is currently being tested using geotechnical analyses.

The understanding of the failure modes and mechanics of rock slope failures is essential to correctly assess the geological hazard of landslide-induced tsunamis during crustal earthquakes along the LOFZ in the Chilean fjordland, which seismogenic nature has been shown by the Aisén earthquake and seismicity found in other LOFZ segment (Lange et al., 2008). Landslide volumes and velocities are critical parameters for tsunami modelling that are directly related to landslide mechanics, as detailed by Clavero et al. (2008) and Naranjo et al. (2009). Furthermore, knowledge of the relation-ships of the landslides with structural, geotechnical and geomorphological characteristics of the slopes will allow the more significant conditioning factors for landslide triggering during earthquakes in fjord coastal environments to be defined. This will assist future landslide susceptibility assessments in Aisén and other fjords close to the seismogenic LiquiñeOfqui Fault Zone.

\section{Acknowledgements}

This work was funded by the Fondecyt Project $\mathrm{N}^{\mathrm{o}}$ 11070107 and the Millenium Nucleus International Center of Earthquake Research. We thank A. Pavez, L. Lara, S. Barrientos and M. Arenas for their fruitful discussions, G. Orozco for his support in field work and S. Rebolledo, J. Le Roux and referees J. Cembrano, J. Naranjo and A. Hauser for their helpful reviews of the draft manuscript.

\section{References}

Arenas, M.; Naranjo, J.; Clavero, J.; Lara, L. 2008. Earthquake-induced landslides: susceptibility mapping for crisis management. In Congreso Geológico Argentino, No. 17, Actas 1: 255. Salvador de Jujuy.

Barrientos, S.; Bataille, K.; Aranda, C.; Legrand, D.; Báez, J.C.; Agurto, H.; Pavez, A.; Genrich, J.; Vigny, C.; Bondoux, F. 2007. Complex sequence of earthquakes in Fjordland, Southern Chile. In Proceedings Geosur 2007: 21. Santiago.

Cembrano, J.; Hervé, F. 1993. The Liquiñe-Ofqui Fault Zone: a major Cenozoic strike-slip duplex in the Southern Andes. In International Symposium on Andean Geodynamics, No. 2: 175-178. Oxford.

Cembrano, J.; Lara, L.; Lavenu, A.; Hervé, F. 2007. Long-term and short-term kinematic history of the Liquiñe Ofqui fault zone, southern Chile: a review and implications for geologic hazard assessment. In Proceedings Geological Society of America Annual Meeting, Denver.

Cembrano, J.; Lavenu, A.; Reynolds, P.; Arancibia, G.; López, G.; Sanhueza, A. 2002. Late Cenozoic transpressional ductile deformation north of the Nazca-South America-Antarctica triple junction. Tectonophysics 354: 289-314.

Clavero, J.;Arenas, M.; Naranjo, J.; Lara, L. 2008. Parameterization of earthquake-induced landslides for tsunami modelling in southern Chile. In Congreso Geológico Argentino, No. 17, Actas 1: 267. Salvador de Jujuy.

Comte, D.; Gallego, A.; Russo, R.; Murdie, R.; VanDecar, 
J. 2007. The Aysen (Southern Chile) 2007 seismic swarm: volcanic or tectonic origin? Eos Transactions, AGU, 88 (23), Joint Assembly Supplement.

Global CMT Catalog. 2008. Global Centroid Moment Tensor Catalog. www.globalcmt.org.

Keefer, D.K. 1984. Landslides caused by earthquakes. Geological Society of America Bulletin 95: 406421.

Lange, D.; Cembrano, J.; Rietbrock, A.; Haberland, C.; Dahm, T.; Bataille, K. 2008. First seismic record for intra-arc strike-slip tectonics along the LiquiñeOfqui fault zone at the obliquely convergent plate margin of the Southern Andes. Tectonophysics, doi: 10.1016/j.tecto.2008.04.014.

Lahsen,A.; González-Ferrán, O.; Innocenti, F.; Manetti, P.; Mazzuoli, R.; Omarioni, R.; Tamponi, M.S. 1997. New occurrence of orogenic volcanism along Liquiñe-Ofqui fault system: the Río Pescado volcanic centers, Southern Andes $\left(45^{\circ} 30^{\prime} \mathrm{S}, 73^{\circ} 04^{\prime} \mathrm{W}\right)$. In Congreso Geológico Chileno, No. 8, Actas 1: 108-112. Antofagasta

NEIC. 2008. National Earthquake Information Center, U.S. Geological Survey. http://earthquake.usgs. gov/regional/neic

Naranjo, J.A.; Arenas, M.; Clavero, J.; Muñoz, O. 2009. Efectos de la crisis sísmica de Aisén 2007. Andean Geology 36 (1): 137-145.

Niemeyer, H.; Skarmeta, J.; Fuenzalida, R.; Espinosa, W. 1984. Hojas Península de Taitao y Puerto Aisén,
Región de Aisén del General Carlos Ibáñez del Campo. Servicio Nacional de Geología y Minería, Carta Geológica de Chile, No. 60-61: 80 p., 1 mapa escala 1:500.000.

Pavez, A.; Sepúlveda, S.A.; Aguilera, R. 2007. Remote sensing analysis of landslides and coastal changes after the 2007 Aysén Mw 6.2 earthquake. In Geosur 2007: 120 p. Santiago.

Sepúlveda S.A.; Murphy, W.; Jibson, R.W.; Petley, D.N. 2005a. Seismically-induced rock slope failures resulting from topographic amplification of strong ground motions: The case of Pacoima Canyon, California. Engineering Geology 80: 336-348.

Sepúlveda S.A.; Murphy, W.; Petley, D.N. 2005b. Topographic controls on coseismic rock slides during the 1999 Chi-Chi earthquake, Taiwan. Quarterly Journal of Engineering Geology and Hydrogeology 38: 189-196.

Sepúlveda, S.A.; Serey, A.; Pavez, A.; Barrientos, S.; Lara, M. 2008a. Analysis of earthquake-induced landslides during the 2007 Aysén Fjord seismic swarm, Chilean Patagonia $\left(45.5^{\circ} \mathrm{S}\right)$. In International Geological Congress, No. 33. Proceedings, paper GHZ04203L. Oslo.

Sepúlveda, S.A.; Serey, A.; Lara, M.; Rebolledo, S. 2008 b. Deslizamientos cosísmicos asociados al terremoto del fiordo aysén de 2007, sur de Chile. In Congreso Geológico Argentino, No. 17, Actas 1: 316-317. Salvador de Jujuy.

Manuscript received: October 6, 2008; accepted: November 4, 2008

\section{GLOSSARY}

Rock Slope Failures: Landslides (mass movements) originated in slopes where the failure occurs in the rock mass. They include rock slides, rock block slides, rock falls, rock avalanches and rock slumps.

Tsunamigenic Landslides: Landslides (mass movements) that generate tsunami waves. They can be submarine or subaerial in coastal slopes.

The definition of different types of rock slope failures used in this work is based on the classification of earthquake-induced landslides by Keefer (1984):

Rock Avalanches: Landslides that disintegrate into streams of rock fragments that can travel several kilometres on slopes of a few degrees at velocities of hundreds of kilometres per hour.

Rock Block Slides: One or few blocks that slide on basal shear surfaces that are discontinuities that dip out of slopes, allowing the blocks to move without significant distortion.

Rock Falls: Individual boulders or disrupted masses of rock that descend slopes by bouncing, rolling or free fall.

Rock Slides: Rock masses that are disordered during movement into masses of rock fragments and blocks that slide on planar or gently curved surfaces. 